\title{
Bokashi compost and biofertilizer increase lettuce agronomic variables in protected cultivation and indicates substrate microbiological changes
}

\author{
Fernando Teruhiko Hataa, Felipe Alvares Spagnuolo ${ }^{b}$, Maria Tereza de Paulaa, Amanda Aleixo Moreira ${ }^{a}$, \\ Mauricio Ursi Venturaa, Gustavo Adolfo de Freitas Fregonezic ${ }^{c}$ André Luiz Martinez de Oliveiraa \\ aUniversidade Estadual de Londrina, Londrina, Brazil. 'Instituto de Desenvolvimento Rural do Paraná - lapar-Emater, Cornélio Procópio, \\ Brazil. 'Centro Universitário Filadélfia, Londrina, Brazil
}

\section{A B S TR A C T}

The aim of the study was to evaluate agronomic productive variables of iceberg lettuce and soil microbiological variables for two crop cycles by using organic inputs. The treatments were as follows: control (no fertilization); Bokashi compost (20 g per plant); Penergetic-k plus Penergetic-p bio-activators (both at $1.5 \mathrm{~g}$ per litre of water, applied to the substrate and plant, respectively); and biofertilizer at different concentrations $(2.5,5.0,7.5$, and $10 \%$ dilutions in water). Biofertilizer concentrations were applied during five fertigation times per day in the first crop experiment and in single daily fertigation in the second crop experiment. Agronomic productive variables evaluated were: total mass, commercial mass, discarded leaves mass, stem diameter, commercial head diameter and plant height. Soil microbial biomass carbon, basal soil respiration and metabolic quotient were evaluated for substrate microbial quality measurement. In the first cycle, plants treated with Bokashi or Penergetic presented superior total mass, commercial mass and commercial head diameter of lettuce, while plants treated with biofertilizer did not exhibit improvement and presented tipburn in some plants, when compared to control. In the second cycle, the use of Bokashi and biofertilizers improved the total mass and commercial head diameter, compared to control. Higher than control microbial biomass was achieved with biofertilizer concentrations and Bokashi. Lower metabolic quotient $\left(q \mathrm{CO}_{2}\right)$ was observed for all the treatments, when compared to control. Soil microbial quality data corresponded to better lettuce yields.

Key words: Organic agriculture; Lactuca sativa L.; Penergetic; Agroecology; microbial soil quality.

\section{INTRODUCTION}

Lettuce, Lactuca sativa L., production in the tropics hot seasons is limited by high temperatures and excessive rain. Cultivation in protected cultivation such as greenhouses and high tunnels is an effective alternative to ensure year-round production as well as greater yields due to higher effectiveness of pest and disease control (Rebouças et al., 2015). Protected cultivation provides conditions to cultivate during the summer and winter months when open field conditions are not feasible. However, intensive crop production under protected environment may favor salinization and soil contamination with pathogens, which in turn would limit yields. Aiming to avoid these problems, the cropping of lettuce in substrates maintained in pots, slabs or bended gutters has been noted as an important alternative (Claro, 2013).
Organic farming is an agricultural system that not only aims to reduce or even eliminate pesticide residues in products but also searches for a broader context of agricultural sustainability in economic, environmental, and social sphere. Demand for organic food is continuously increasing, global organic market of food and drink reached 97 billion US dollars in 2017 (Sahota, 2019). Nevertheless, to obtain high yields and quality under organic farming requires the integration of agronomic, ecologic and social knowledge. To increase crop yields under organic management, studies on fertilizers and other inputs allowed in such farming systems must be conducted.

Several certified inputs for organic agriculture have been used and some of them have general recommendation, usually based on traditional knowledge. Then studies for each crop demand are important for a sustainable use of natural resources. Bokashi compost is an organic

\footnotetext{
${ }^{*}$ Corresponding author:

Fernando Teruhiko Hata, Universidade Estadual de Londrina, Londrina, Brazil. Email: hata@uel.br
}

Received: 21 March 2020; $\quad$ Accepted: 22 July 2020 
amendment prepared with a mixture of fermented organic matter (lactic, acetic, alcoholic, propionic and butyric fermentation) of animal and plant origin (Siqueira and Siqueira, 2013), with microbial inoculum that reduce time of preparation resulting in a rich source of beneficial microorganisms (Quiroz and Céspedes, 2019).

EM (Effective Microorganisms) Bokashi was tested with several vegetables with promissory results. For lettuce, diameter, fresh biomass and number of leaves was increased by using Bokashi at $500 \mathrm{~g} \mathrm{~m}^{-2}$ (Goulart et al., 2018). Beetroot (Beta vulgaris L.) and cabbage (Brassica oleracea var. capitata) production were also benefited by Bokashi fertilizations (Silva et al., 2018; Xavier et al., 2019). Arugula and radish intercropping and the results shows that an increase in leaves biomass and length was observed in arugula and increase in radish bulb biomass and volume was achieved (Hata et al., 2019). Parsley (Petroselinum crispum [Mill.] Nym. chlorophyll index was increased with Bokashi treatments (Maass et al., 2020).

Liquid biofertilizers are very popular inputs in organic farming systems and are obtained by aerobic or anaerobic fermentation of organic matter; they provide macro- and microelements needed for balanced plant nutrition (Silva et al., 2007). However, studies are not conclusive about its efficacy in lettuce. For example, studies show that biomass was not improved by using liquid biofertilizer or even reduction in yield was observed (Roel et al., 2007; Dias et al., 2009). Other studies show that increase in number of leaves was observer in lettuce fertilized with biofertilizer compared to mineral fertilizer (Chiconato et al., 2013) and increase of $17 \%$ was observed in lettuce yield (Tošić et al., 2016).

Penergetic ${ }^{\circledR}$ is a commercial input that affects soil biota (soil and plant bio-activator) and has been reported to release fixed phosphorus in the soil, rebalance microorganisms and provide higher energy to the photosynthetic process (Santinato et al., 2014). On previous study, Penergetic increased bulb biomass and volume of radish; however, positive effects on arugula, a leafy vegetable, agronomic variable were not observed (Hata et al., 2019).

These organic inputs may affect the soil microbial community. The soil microbial biomass, which uses organic matter available in the soil for its own establishment, is fundamental to nutrient cycling and organic matter mineralization (Schmidt et al., 2013). Positive effects on microbial characteristics of adding organic matter include increased microbial activity by providing a net of interactions among microorganisms and increasing enzymatic activity (Melero et al., 2006). This in turn improves the soil physical and chemical characteristics (De-Polli and Pimentel, 2005). Microbial biomass carbon is thus a soil quality indicator because it shows changes in decomposition and mineralization of organic residues (Balota et al., 1998).

The objective of the study was to evaluate total mass, commercial mass, discarded leaves mass, stem diameter, commercial head diameter and plant height of iceberg lettuce and soil microbial carbon biomass, basal soil respiration and soil metabolic quotient for two crop cycles under the influence of organic inputs.

\section{MATERIAL AND METHODS}

\section{Lettuce in protected cultivation}

The experiments were conducted in two consecutive crop cycles of iceberg lettuce (Lactuca sativa L.), cv. Amélia, from October 2015 to February 2016 in protected cultivation in

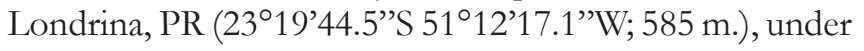
organic farming management practices after strawberry cultivation in the substrate (Fig. 1).

The substrate was prepared according to Claro, 2013. Soil was classified as a clayey Ferralsol that was highly clayey (72.5\% clay; $20.2 \%$ silt and $7.3 \%$ sand; $\mathrm{pHH} 2 \mathrm{O}=5.90 ; \mathrm{P}=$ $4.00 \mathrm{mg} / \mathrm{dm}^{3} ; \mathrm{K}^{+}=0.25 \mathrm{cmol}_{\mathrm{c}} / \mathrm{dm}^{3} ; \mathrm{Ca}^{+2}=4.0 \mathrm{cmol}_{\mathrm{c}} / \mathrm{dm}^{3} ;$ $\mathrm{Mg}^{+2}=1.5 \mathrm{cmol}_{\mathrm{c}} / \mathrm{dm}^{3} ; \mathrm{Al}^{+3}=0.0 ; \mathrm{H}+\mathrm{Al}^{+3}=2.60 \mathrm{cmol}_{\mathrm{c}} /$ $\mathrm{dm}^{3}$; and Organic Matter $=2.20 \%$ ). The substrate was packed in gutters $(0.15 \times 2.40 \mathrm{~m})$, bent to a $45^{\circ}$ angle, and sealed with plastic at the ends (Claro, 2013). The containers were kept on benches $0.70 \mathrm{~m}$ high.

Seedlings were transplanted, and seven plants were planted in each gutter, spaced $0.35 \mathrm{~m}$ apart (October 29, 2015 and December 23, 2015) and harvested on December 17, 2015, and February 15, 2016, for the first and second crop cycles, respectively.

Treatments included the following: Control (water only); Bokashi compost (20 g plant $\left.{ }^{-1}\right)$; Penergetic ${ }^{\circledR}$ bioactivator $\mathrm{k}$ formulation $\left(1.5 \mathrm{~g} \mathrm{~L}^{-1}\right)$ applied to the substrate before planting and Penergetic ${ }^{\circledR} \mathrm{p}\left(1.5 \mathrm{~g} \mathrm{~L}^{-1}\right)$ sprayed on the plants 7 and 21 days after transplanting; and Biofertilizer (2.5, 5.0, 7.5 and $10 \%$ concentrations in water). Biofertilizer and water alone were applied by drippers $\left(40 \mathrm{~mL}_{\text {plant }}{ }^{-1}\right)$ five times per day in the first cycle and one time per day in the second cycle. The number of fertilization periods was reduced because tip-burn symptoms were observed in the first cycle. Biofertilizer "Bioframbov" was prepared according to Claro, 2013. The solution was stirred twice a day for one month to aerate before being using on substrate as fertigation at abovementioned concentrations.

Total mass (TM) (g), commercial mass (after elimination of damaged leaves) (CM) (g), discarded leaves mass (DLM) (g), 


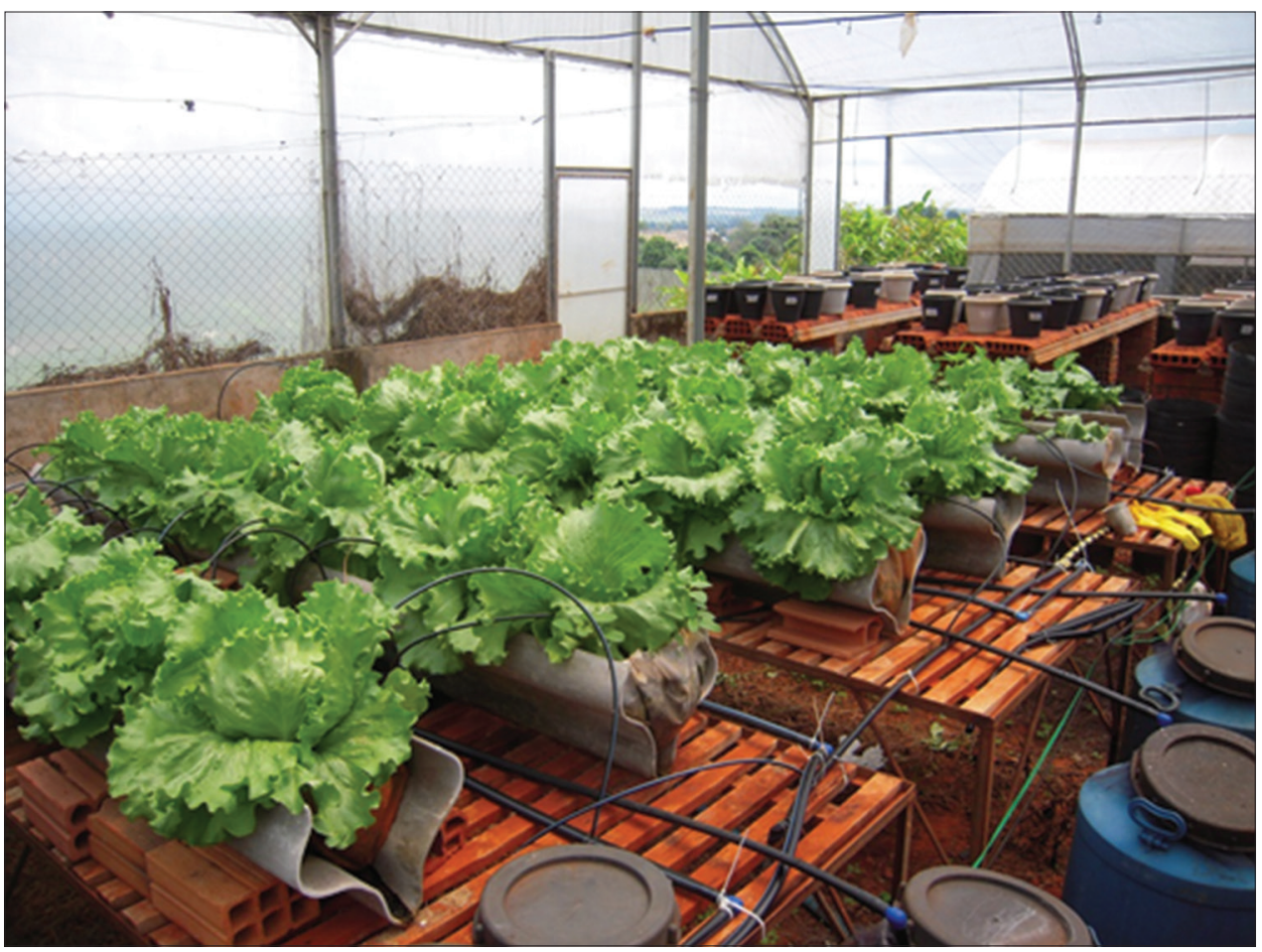

Fig 1. Overview of experiment of lettuce submitted to different concentrations of biofertilizers, Bokashi and Penergetic in protected cultivation

stem diameter (SD) (mm), commercial head diameter $(\mathrm{CHD})(\mathrm{mm})$ and plant height $(\mathrm{PH})(\mathrm{mm})$ were determined.

\section{Substrate microbial analysis}

Microbiological analysis of the substrates was carried out on samples collected after the second crop cycle. Three substrate samples from each treatment were collected, air dried, sieved ( $2 \mathrm{~mm}$ ) and stored at room temperature away from sunlight. Prior to microbiological analysis, subsamples of $50 \mathrm{~g}$ from each sample were placed in sterilized Petri dishes, moistened with $20 \mathrm{~mL}$ of sterilized distilled water and incubated at $28 \pm 1^{\circ} \mathrm{C}$ for seven days to reactivate the soil microorganisms (Gonçalves et al., 2002). After the incubation period, soil microbial biomass carbon (MBC) was determined using the fumigation - extraction method (Silva et al., 2007a). Basal soil respiration (BSR) was determined by quantifying $\mathrm{CO}_{2}$ released by microbial respiration (Silva et al., 2007b). Metabolic quotient $\left(q \mathrm{CO}_{2}\right)$ was calculated as a ratio of BSR by MBC (Anderson and Domsch, 1993).

\section{Experimental design and statistical analysis}

A completely randomized design was used with five replicates. To verify the assumptions for analysis of variance, tests of variance homogeneity and normality were performed with BioEstat 5.0 (Ayres, 2007) software. Thereafter, analysis of variance was performed, and means were compared by Tukey's test $(\alpha=0.05)$ with SASM-Agri (Canteri et al., 2001) software. Pearson correlation between $\mathrm{CM}$ and $q \mathrm{CO}_{2}$ was performed.

\section{RESULTS AND DISCUSSION}

The treatments affected the agronomic variables (Table 1). In the first cycle, treatments with Bokashi and Penergetic provided the greater development and showed improvement in TM, CM and CHD when compared to the control treatment or even treatments that received biofertilizer (all concentrations) (Table 1). Treatments with biofertilizers did not improve agronomic variables and caused tipburn in some plants. Penergetic bioactivator treatment provided increments of 66,65 and $34 \%$ to TM, $\mathrm{CM}$ and $\mathrm{CHD}$, respectively; and Bokashi compost provided 55, 51 and $35 \%$, to TM, CM and CHD, respectively. Both when compared to control.

In the second cycle, Bokashi compost treatments increased lettuce TM, CM, DLM, SD and CHD, when compared to control treatment (Table 1). Penergetic treatment also increased SD and CHD compared to the control. Biofertilizers, which were applied just once a day (in contrast to the first cycle which included five applications a day), generally promoted higher TM, CM, SD and CHD in all concentrations compared to the control.

The increased performance of biofertilizer treatments compared to control in the second cycle probably was triggered by a reduction of biofertilization periods from five to one time per day of fertigation because tipburn was observed only in the first cycle. This symptom occurs due to nutritional imbalance under high temperatures when foliar 
Hata, et al.

\begin{tabular}{|c|c|c|c|c|c|c|}
\hline \multicolumn{7}{|c|}{ First cycle } \\
\hline Treatments & TM (g) & CM (g) & DLM (g) & $\mathrm{SD}(\mathrm{mm})$ & $\mathrm{CHD}(\mathrm{mm})$ & $\mathrm{PH}(\mathrm{mm})$ \\
\hline Control & $428.80^{b}$ & $337.60^{b}$ & $91.20^{\mathrm{a}}$ & $19.46^{b}$ & $123.75^{b}$ & $139.51^{\mathrm{ab}}$ \\
\hline Bio $2.5 \%$ & $419.00^{b}$ & $342.50^{b}$ & $121.80^{\mathrm{a}}$ & $19.77^{b}$ & $113.15^{b}$ & $143.36^{\mathrm{ab}}$ \\
\hline Bio $5.0 \%$ & $438.20^{b}$ & $302.00^{b}$ & $136.20^{\mathrm{a}}$ & $22.96^{\mathrm{ab}}$ & $116.24^{b}$ & $132.30^{\mathrm{b}}$ \\
\hline Bio $7.5 \%$ & $424.00^{b}$ & $276.60^{b}$ & $147.40^{\mathrm{a}}$ & $20.69^{b}$ & $109.40^{b}$ & $145.98^{\mathrm{ab}}$ \\
\hline Bio $10.0 \%$ & $436.50^{b}$ & $317.75^{b}$ & $129.00^{a}$ & $20.01^{b}$ & $140.59^{\mathrm{ab}}$ & $148.69^{a b}$ \\
\hline Penergetic & $713.20^{a}$ & $557.20^{\mathrm{a}}$ & $156.00^{\mathrm{a}}$ & $22.59^{\mathrm{ab}}$ & $165.94^{a}$ & $161.33^{\mathrm{ab}}$ \\
\hline Bokashi & $664.20^{\mathrm{a}}$ & $508.40^{a}$ & $155.80^{a}$ & $24.71^{\mathrm{a}}$ & $166.92^{a}$ & $175.79^{a}$ \\
\hline C.V. $(\%)$ & 19.41 & 18.34 & 24.14 & 8.16 & 12.14 & 34.00 \\
\hline$F$ value & 8.37 & 12.11 & 2.51 & 5.88 & 11.41 & 2.04 \\
\hline \multicolumn{7}{|c|}{ Second cycle } \\
\hline Control & $442.40^{\circ}$ & $295.60^{b}$ & $146.80^{\circ}$ & $17.13 d$ & $106.80^{b}$ & $147.60^{a}$ \\
\hline Bio $2.5 \%$ & $717.50^{\mathrm{ab}}$ & $483.00^{\mathrm{a}}$ & $234.50^{\mathrm{bc}}$ & $18.00^{\circ} d$ & $151.50^{\mathrm{a}}$ & $144.40^{a}$ \\
\hline Bio $5.0 \%$ & $642.40^{\mathrm{ab}}$ & $435.20^{a}$ & $237.00^{\mathrm{bc}}$ & $18.60^{\mathrm{bc} d}$ & $151.60^{\mathrm{a}}$ & $161.80^{a}$ \\
\hline Bio $7.5 \%$ & $811.00^{a}$ & $469.00^{\mathrm{a}}$ & $342.00^{\mathrm{a}}$ & $21.80^{a}$ & $154.80^{a}$ & $170.20^{a}$ \\
\hline Bio $10.0 \%$ & $642.00^{\mathrm{ab}}$ & $408.80^{a b}$ & $233.20^{\mathrm{bc}}$ & $20.30^{a b c}$ & $156.80^{a}$ & $164.20^{\mathrm{a}}$ \\
\hline Penergetic & $577.00^{\text {bc }}$ & $362.80^{\mathrm{ab}}$ & $214.20^{\mathrm{bc}}$ & $20.50^{\mathrm{ab}}$ & $155.75^{a}$ & $153.40^{\mathrm{a}}$ \\
\hline Bokashi & $760.80^{\mathrm{ab}}$ & $458.80^{a}$ & $302.00^{\mathrm{ab}}$ & $21.80^{\mathrm{a}}$ & $168.60^{a}$ & $152.20^{a}$ \\
\hline C.V. (\%) & 15.04 & 16.13 & 20.23 & 5.88 & 12.19 & 11.57 \\
\hline F value & 7.44 & 4.77 & 7.52 & 12.71 & 5.82 & 1.35 \\
\hline
\end{tabular}

C.V.: Coefficient of variation; Means followed by the same letter in the column did not differ significantly from each other, Tukey, $p>0.05$

expansion increases. Previous study failed to substitute mineral solution with 10\% biofertilizer (Dias et al., 2009).

Lower biofertilizer concentrations $(2.5 \%)$ appear to be sufficient for lettuce development. In the second cycle, greater TM, CM and CHD, which are commercially important aspects, were improved when compared to control. Also, these variables were similar to what was achieved by plants treated with Bokashi, a common fertilizer used in organic agriculture. Our results corroborate with previous studies in which minimal biofertilizer doses was enough for suitable lettuce production (Pereira et al., 2010; Chiconato et al. 2014). Improvements in iceberg lettuce (cv. OGR 326, Gloriosa, and Laurel) yields grown in a greenhouse, were previously reported by using the biofertilizer Bioembrapa (150 kg N ha ${ }^{-1}$ ) (Ludke et al., 2009). The authors obtained a mean of $512 \mathrm{~g}$ plant $^{-1}$, a value similar to that found in the present study. Other biofertilizers based on cattle manure (5\% concentration in transplanting and $0.5 \%$ twice a week) improved 59\% the commercial mass compared to the control in an open field study (Escobar et al., 2011).

Bokashi compost triggered greater development in lettuce (Brito et al., 2002; Goulart et al., 2018). The number of pods of green beans was higher when Penergetic was applied (Brito et al., 2012); increased yields were also found for sugar beet (Jakiene et al., 2009) and radish (Hata et al., 2019). On the other hand, different from the present study, Penergetic use did not improve arugula agronomic variables (bulb biomass and diameter) (Hata et al., 2019). These studies did not explained the factors in which affected the crop improvement. In the present study, soil microbial variables are discussed, as follow.

Microbial analysis variables were also affected by the treatments (Table 2). Microbial biomass carbon (MBC) values varied from 72.73 (control) to $230.30 \mathrm{mg} \mathrm{C} \mathrm{kg}^{-1}$ soil (Bokashi). All biofertilizer concentrations increased MBC when compared to control, and greater increases were found for lower concentrations (2.5 and 5\%).

Higher values of $\mathrm{MBC}$ occurred when biofertilizer and Bokashi were used. Since microorganisms consumes soil organic matter for maintenance and multiplication, this suggests higher soil quality because many nutrients may remain incorporated in $\mathrm{MBC}$ rather than immobilized in its matrix or free for lixiviation (Gama-Rodrigues and Gama-Rodrigues, 2008). Nutrients may be easily released to the plants, after microorganisms' decease.

Higher concentrations of biofertilizer (greater than $5 \%$ ) decreased MBC; this may indicate that chemical or microbial imbalance occurred. In general, adding organic matter affects $\mathrm{MBC}$ in the short term and reflects a relative scarcity of soil carbon (C) labile compounds to support the growth of naturally occurring microbial populations (maintained in low populations in the soil) (Lazcano et al., 2013). This immediate response may indicate that the added organic matter is immediately transformed by soil 
Table 2 :Mean ( \pm S.E.M.) microbial carbon biomass (MBC, basal soil respiration (BSR) and soil metabolic quotient $\left(q \mathrm{CO}_{2}\right)$, submitted to biofertilizers, Bokashi and Penergetic. Londrina, Paraná, Brazil, 2016)

\begin{tabular}{lccc}
\hline Treatments & MBC & BSR & $q \mathrm{CO}_{2}$ \\
\hline Control & $72.73^{\mathrm{e}}$ & $0.91^{\mathrm{b}}$ & $12.75^{\mathrm{a}}$ \\
Bio $2.5 \%$ & $193.94^{\mathrm{b}}$ & $0.56^{\mathrm{d}}$ & $2.89^{\mathrm{e}}$ \\
Bio $5.0 \%$ & $193.94^{\mathrm{b}}$ & $0.76^{\mathrm{bc}}$ & $3.92^{\mathrm{de}}$ \\
Bio $7.5 \%$ & $118.18^{\mathrm{d}}$ & $0.82^{\mathrm{bc}}$ & $6.96^{\mathrm{bc}}$ \\
Bio $10.0 \%$ & $166.67^{\mathrm{c}}$ & $0.66^{\mathrm{cd}}$ & $4.02^{\mathrm{de}}$ \\
Penergetic & $100.00^{\mathrm{de}}$ & $0.79^{\mathrm{bc}}$ & $7.92^{\mathrm{b}}$ \\
Bokashi & $230.30^{\mathrm{a}}$ & $1.15^{\mathrm{a}}$ & $4.99^{\mathrm{cd}}$ \\
C.V. & 7.27 & 7.69 & 11.85 \\
F value & 104.98 & 27.68 & 66.77 \\
\hline
\end{tabular}

C.V.: Coefficient of variation; Means followed by the same letter in the column did not differ significantly from each other. Tukey; $p>0.05$ )

microbiota and provides nutrients to short experiment crops (such as lettuce).

MBC variable alone does not always equate to greater activity or decomposition. Many other factors may influence these regardless of microbial biomass. Carbon biomass can be only one metric for soil health/quality but it is difficult to interpret and most be considered in context of other soil metrics and factors. Therefore, other variables for microbial quality status in soil must be used. Variation in $\mathrm{CO}_{2}$ emission may be related to soil nutritional content and MBC cycling (Emmerling et al., 2000), and high BSR values may indicate a perturbated or even highly productive environment (Islan and Weil, 2000). Then, metabolic quotient $\left(q \mathrm{CO}_{2}\right)$ is more representative of the soil microbial activity (Anderson, 2003). Low $q \mathrm{CO}_{2}$ indicates higher incorporation of $\mathrm{C}$ by cells, which diminishes $\mathrm{CO}_{2}$ emission to the atmosphere. In contrast, higher values indicate that the microbial population may be in stress due to adverse situations that demand greater $\mathrm{C}$ consumption for sustenance (Anderson and Domsch, 2010). In general, stable agroecosystems present lower $q \mathrm{CO}_{2}$ values.

The $q \mathrm{CO}_{2}$ means varied from 2.89 to $12.75 \mathrm{mg} \mathrm{C}^{-} \mathrm{CO}_{2}^{-1}$ $\mathrm{BSR}^{-1} \mathrm{~h}^{-1}$, for biofertilizer $2.5 \%$ and control, respectively. Control mean were higher than other treatment means and reflected $\mathrm{C}$ loss and unbalanced microbial activity in the soil. On the other hand, treatments decreased $q \mathrm{CO}_{2}$ values and triggered soil microbiota to a higher balanced pattern and agronomic variables. Plants that was submitted to biofertilizers or Bokashi showed greater TM and CHD, agronomic variables related to plant development, compared to control and the opposite was observed for $q \mathrm{CO}_{2}$ which was confirmed by a negative correlation ( $p<0.05$; $\mathrm{e}-0.84)$ between $\mathrm{CM}$ and $q \mathrm{CO}_{2}$.

In general, studies focus on chemical and physical quality of soils. In the present work we showed that biofertilizer and Bokashi improve microbiological substrate quality and agronomic variables of lettuce grown in the summer in protected cultivation. The role of microorganisms on lettuce have been studied with promissory results: Pseudomonas sp. and Trichoderma aureoviride (Martins Filho et al., 2019), Torulaspora globosa (Cabrini et al., 2019) and Bacillus subtilis (Lee et al., 2020) increased lettuce growth. The next steps may be the identification of biofertilizer and Bokashi microorganisms' composition for a better understanding of "who they are" and if there is a possibility of isolate them to study their specificity in plant growth promotion.

\section{CONCLUSIONS}

The results show the viability of using substrates and organic fertilizers to produce iceberg lettuce in protected cultivation in the summer. Biofertilizers provided better results in the second cycle, when only one fertigation period was used ( $2.5 \%$ concentration). Bokashi improved agronomic variables in the two production cycles compared to control. Application of the fertilizers Bokashi and biofertilizers provided higher microbial biomass carbon and lower $q \mathrm{CO}_{2}$, indicating improving in biological soil conditions.

\section{Disclosure statement}

The authors declare that there is no conflict of interest regarding the publication of this manuscript.

\section{ACNOWLEDGEMENTS}

The authors would like to thank the research funding agencies Conselho Nacional de Desenvolvimento Científico e Tecnológico - CNPq and Coordenação de Aperfeiçoamento de Pessoal de Nível Superior - CAPES, for the scholarships granted.

\section{Authors' contributions}

FTH, FAS and MUV and analyzed the results and prepared the manuscript. MUV, GAFF and ALMO designed the experiments and revised the manuscript. FTH, MTP and AAM performed the experiments and prepared the manuscript.

\section{REFERENCES}

Anderson, T. H. 2003. Microbial eco-physiological indicators to asses soil quality. Agric. Ecosyst. Environ. 98: 285-293.

Anderson, T. H. and K. H. Domsch. 1993. The metabolic quotient for $\mathrm{CO}_{2}\left(\mathrm{qCO}_{2}\right)$ as a specific activity parameter to assess the effects of environmental conditions such as $\mathrm{pH}$ on the microbial biomass of forest soils. Soil Biol. Biochem. 25: 393-395. 
Anderson, T. H. and K. H. Domsch. 2010. Soil microbial biomass: The ecophysiological approach. Soil Biol. Biochem. 42: 2039-2043.

Ayres, M. 2007. BioEstat 5.0: Aplicações Estatísticas nas Áreas das Ciências Biológicas e Médicas. $5^{\text {th }}$ ed. Conselho Nacional de Desenvolvimento Científico e Tecnológico, Sociedade Civil Mamirauá, Brasília, Belém.

Balota, E. L., A. Colozzi-Filho, D. S. Andrade and M. Hungria. 1998. Biomassa microbiana e sua atividade em solos sob diferentes sistemas de preparo e sucessão de culturas. Rev. Bras. Ciênc. Solo. 22: 641-649.

Brito, O. R., F. K. Dequech and R. M. Brito. 2012. Use of Penergetic products $\mathrm{P}$ and $\mathrm{K}$ in the snap bean production. Annu. Rep. Bean Improv. Coop. 55: 279-280.

Brito, T. D., C. D. S. Rodrigues and C. A. Machado. 2002. Avaliação do Desempenho de Substratos para Produção de Mudas de Alface em Agricultura Orgânica. Vol. 20. Annals of the $42^{\circ}$ Congresso Brasileiro de Olericultura, p. 1-5.

Cabrini, P. G., F. C. Sala and M. M. R. Magri. 2019. Torulaspora globosa: Rhizosphere yeast promoting lettuce growth on seedlings and under field conditions. Hortic. Bras. 37: 266-271.

Canteri, M. G., R. A. Althaus, J. S. V. Filho, E. A. Giglioti and C. V. Godoy. 2001. SASM-Agri: Sistema para análise e separação de médias em experimentos agrícolas pelos métodos Scott-Knott. Tukey e Duncan. Rev. Bras. Agrocomputação. 1: 18-24.

Chiconato, D. A., F. Simoni, J. A. Galbiatti, C. F. Franco and A. D. Caramelo. 2013. Resposta da alface à aplicação de biofertilizante sob dois níveis de irrigação. Biosci. J. 29: 392-399.

Chiconato, D. A., J. A. Galbiatti, M. Junior, C. F. Franco and A. D. Caramelo. 2014. Bovine biofertilizer and irrigation layers on lettuce development and leaf chlorophyll. Comun. Sci. 5: 140147.

Claro, S. A. 2013. Leitos e Substratos Para Produção Orgânica de Hortaliças: Controle da Murcha Bacteriana. Agrolivros, p. 280.

De-Polli, H. and M. S. 2005. Pimentel, Indicadores de qualidade do solo. In: A. M. Aquino, R. L. Assis (Eds.), Processos Biológicos no Sistema Solo-planta: Ferramentas Para Uma Agricultura Sustentável. Embrapa-SCT, Brasília, pp. 17-28.

Dias, N. D. S., A. A. F. de Brito, O. N. D. Neto, R. B. de Lira and R. F. de Brito. 2009. Produção de alface hidropônica utilizando biofertilizante como solução nutritiva. Rev. Caatinga. 22: 158162.

Emmerling, C., C. Liebner, M. Haubold-Rosar, J. Katzur and D. Schröder. 2000. Impact of application of organic waste materials on microbial and enzyme activities of mine soils in the Lusatian coal mining region. Plant Soil. 220: 129-138.

Gama-Rodrigues, R. E. and C. A. Gama-Rodrigues. 2008. Biomassa microbiana e ciclagem de nutrientes. In: G. A. Santos (Ed.), Fundamentos da Matéria Orgânica do Solo: Ecossistemas Tropicais e Subtropicais. $2^{\text {nd }}$ ed. pp.159-182.

Gonçalves, A. S., M. T. Monteiro, J. G. M. Guerra and H. De-Polli. 2002. Biomassa microbiana em amostras de solos secadas ao ar e reumedecidas. Pesqui. Agropec. Bras. 37: 651-658.

Goulart, R. G. T., C. A. dos Santos, C. M. de Oliveira, E. S. P. Costa, F. A. de Oliveira, N. F. de Andrade and M. G. F. do Carmo. 2018. Desempenho agronômico de cultivares de alface sob adubação orgânica em Seropédica, RJ. Rev. Bras. Agropec. Susten. 8: 66-72.

Hata, F. T., M. U. Ventura, V. Sousa and G. A. F. Fregonezi. 2019. Low-cost organic fertilizations and bioactivator for arugularadish intercropping. Emir. J. Food Agric. 31: 773-778.

Islan, K. R. and R. R. Weil. 2000. Soil quality indicator proprieties in mid-Atlantic soils as influenced by conservation management. J.
Soil Water Conserv. 55: 69-78.

Jakiene, E., V. Venskutonis and V. Liakas. 2009. Fertilization of sugar beetroot with ecological fertilizers. Agron. Res. 7: 269-276.

Lazcano, C., M. Gómez-Brandón, P. Revilla and J. Domínguez. 2013. Short-term effects of organic and inorganic fertilizers on soil microbial community structure and function. Biol. Fertil. Soils. 49: 723-733.

Lee, S., C. S. Tr Tr, W. J. Lee, C. Y. Jeong, H. A. Truong, N. Chung, N., C. S. Kang and H. Lee. 2020. Bacillus subtilis strain L1 promotes nitrate reductase activity in Arabidopsis and elicits enhanced growth performance in Arabidopsis, lettuce, and wheat. J. Plant Res. 133: 231-244.

Lüdke, I., R. B. Souza, F. V. Resende, F. M. S. Delvico, S. M. Meireles and D. O. Braga. 2009. Produção Orgânica de Alface Americana Fertirrigada com Biofertilizantes em Cultivo Protegido. Vol. 27. In: Annals of the $49^{\circ}$ Congresso Brasileiro De Olericultura, pp. 3370-S3377.

Martins Filho, A. P., E. V. Medeiros, J. G. Barbosa, J. M. P. Barbosa, J. Kuklinsky-Sobral and C. Souza-Motta. 2019. Combined effect of Pseudomonas sp. and Trichoderma aureoviride on lettuce growth promotion. Biosci. J. 35: 419-430.

Maass, V., C. Céspedes and C. Cárdenas. 2020. Effect of Bokashi improved with rock phosphate on parsley cultivation under organic greenhouse management. Chil. J. Agric. Res. 80: 444-451.

Melero, S., J. C. R. Porras, J. F. Herencia and E. Madejon. 2006. Chemical and biochemical properties in a silty loam soil under conventional and organic management. Soil Till. Res. 90: 162170.

Pereira, M. A. B., J. C. Silva, J. F. Mata, J. C. Silva, G. A. Freitas, L. B. Santos and I. R. Nascimento. 2010. Uso de biofertilizante foliar em adubação de cobertura da alface cv. Verônica. Appl. Res. Agrotec. 3: 129-134.

Quiroz, M. and C. Céspedes. 2019. Bokashi as an amendment and source of nitrogen in sustainable agricultural systems: A review. J. Plant Nutr. Soil Sci. 19: 237-248.

Rebouças, P. M., Í. F. Dias, M. A. Alves and J. A. D. B. Filho. 2015. Radiação solar e temperatura do ar em ambiente protegido. Rev. Agrogeoambiental. 7: 115-125.

Roel, A. R., L. A. K. Leonel, S. P. Favaro, M. Zatarim, C. M. V. Momeso and M. V. Soares. 2007. Avaliação de fertilizantes orgânicos na produção de alface em Campo Grande, MS. Sci. Agraria. 8: 325-329.

Sahota, A. 2019. The global market for organic food and drink. In: The World of Organic Agriculture. Statistics and Emerging Trends 2019. Research Institute of Organic Agriculture (FiBL) and IFOAM-Organics International, Rheinbreitbach, Germany, pp. 145-150.

Santinato, R., A. L. T. Fernandes, R. O. Silva and F. Santinato. 2014. Efeito do Bioativador Penergetic $p$ e Penergetic k no Desenvolvimento Vegetativo do Cafeeiro em Solo nu e Cultivado Associado à Fertilizantes Fosfatados e Esterco de Curral. In: Annals of the $40^{\circ}$ Congresso Brasileiro de Pesquisas Cafeeiras, p. 1-2.

Schmidt, R. O., R. S. Sana, F. K. Leal, R. Andreazza, F. A. D. Camargo and E. J. Meurer. 2013. Biomassa e atividade microbiana do solo em sistemas de produção olerícola orgânica e convencional. Cienc. Rural. 43: 270-276.

Silva, A. F., J. M. Pinto, C. R. R. França, S. C. Fernandes, T. C. A. Gomes, M. S. L. Silva. 2007. Preparo e uso de Biofertilizantes Líquidos. Technican Communication Number. 130. Embrapa Semi-Árido, p4. 
Silva, E. E., P. H. S. de Azevedo and H. De-Polli. 2007a. Determinação do Carbono da Biomassa Microbiana do Solo (BMS-C). Technican Communication. 98. Embrapa Agrobiologia. p4.

Silva, E. E., P. H. S. de Azevedo and H. De-Polli. 2007b. Determinação da Respiração Basal (RBS) e Quociente Metabólico do solo $\left(\mathrm{qCO}_{2}\right)$. Technican Communication Number. 99. Embrapa Agrobiologia, p. 4.

Silva, P. N. L., N. B. L. Lanna and A. I. I. Cardoso. 2018. Doses de Bokashi em cobertura na produção de beterraba. Rev. Agric.
Neotrop. 5: 28-34.

Siqueira, A. P. P., M. F. B. Siqueira. 2013. Bokashi: Adubo orgânico fermentado. Manual Técnico. 40: 16.

Tošić, I., Z. Golić and A, Radosavac. 2016. Effects of the application of biofertilizers on the microflora and yield of lettuce (Lactuca sativa L.). Acta Agric. Serb. 21: 91-98.

Xavier, M. C. G., C. A. Santos, E. S. P. Costa and M. G. F. Carmo. 2019. Produtividade de repolho em função de doses de Bokashi. Rev. Agric. Neotrop. 6: 17-22. 